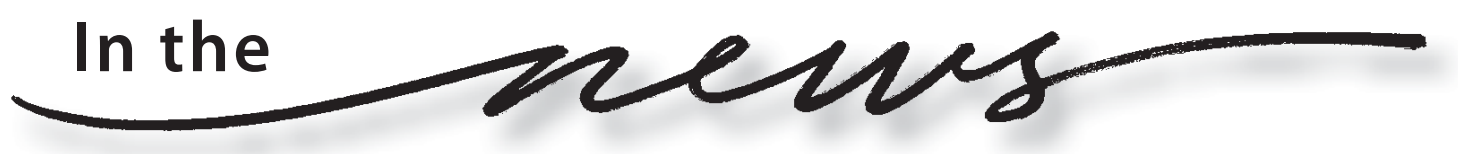

You'll find the ACRL Annual Report for fiscal year 2005 in this issue. We've reorganized the report to follow the structure of ACRL's new strategic plan, which the association began implementing in 2004-05. The Annual Report provides an overview of ACRL's accomplishments for the year, in addition to a year-end financial report and a list of ACRL staff and their duties.

Some major achievements in fiscal 2005 were the highly successful 12th National Conference, "Currents and Convergence: Navigating the Rivers of Change," which for the first time featured a virtual component, and Choice's partnership with R.R. Bowker to produce Resources for College Libraries, an online successor to the popular Books for College Libraries, which was last published in 1988. For a more complete look at what ACRL was working on in 2004-05, make a point to turn to page 797 .

Two of this month's articles deal with information sharing within and among libraries.
"Something wiki this way comes" (page 775) explores how the use of wiki technology can enhance information sharing among librarians. Ohio University's library has put wiki to work to keep those staffing the information desk up-to-date on crucial information. "Reaching out: The Pennsylvania State System of Higher Education librarians take stock of accomodative services" (page 792) provides an example of one library system's approach to keeping informed on options for providing accommodative services.

The focus of this issue's Internet Resources article is music. In it you'll find a host of online materials covering pop, jazz, folk, opera, and more.

To help you get started with planning your schedule for the Midwinter Meeting, a list of ACRL events and meetings in San Antonio is include in this issue on page 782 .

-Stephanie Orphan, Editor-in-chief sorphan@ala.org

\section{Make NO Mistake} According to a recent readership survey of librarians and higher education faculty:

- 79\% of subscribers polled rely on CHOICE reviews to make their material selections!

- $51 \%$ use CHOICE reviews as their primary collection development tool!

- Compared to 10 other leading review sources, CHOICE reviews were preferred by 5 tol!

- For the best short critical evaluations of new titles arywhere, readers favored CHOICE 8 to 1 !

If you pu rchase materlal for your college Ilbrary collection and are lookng for exciting new ways to make selecting books and Intemet resources easker faster, and more efflclent than ever...

\section{There Is Only One CHOICE!}

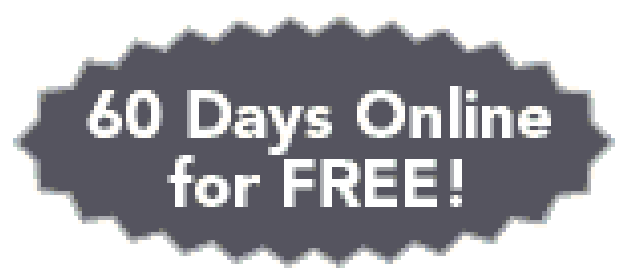

To ty CholceRevlews.on line Pasword or ChoceRevlews.online Stte Ucense Editlon FREE for 60 days clidk on www CholceRevlews.org. To aubsabe to CHOlCE Hagazne or Revews On Cards, contad us at ww.ala.org/act/holce, or call 240 b46-7027.

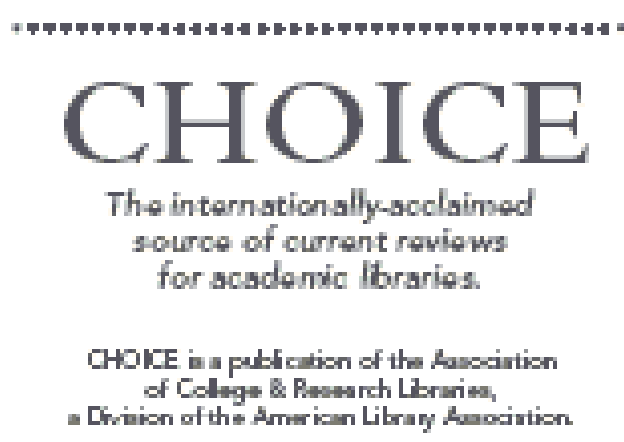

